\title{
The Development of Excitatory Synapses in Cultured Spinal Neurons
}

\author{
Richard J. O'Brien, ${ }^{1,2,3}$ Andrew L. Mammen, ${ }^{1,2}$ Seth Blackshaw, ${ }^{2}$ Michael D. Ehlers, ${ }^{1,2}$ Jeffrey D. Rothstein, ${ }^{3}$ \\ and Richard L. Huganir ${ }^{1,2}$ \\ ${ }^{1}$ Howard Hughes Medical Institute, and Departments of ${ }^{2}$ Neuroscience and ${ }^{3}$ Neurology, Johns Hopkins University School \\ of Medicine, Baltimore, Maryland 21205
}

Immunohistochemical studies of synapses in the CNS have demonstrated that glutamate receptors (GluRs) are concentrated at postsynaptic sites in vivo and in vitro (Baude et al., 1995). The mechanisms leading to receptor clustering at excitatory synapses are far less understood than those governing acetylcholine receptor accumulation at the neuromuscular junction (Hall and Sanes,1993) or glycine receptor aggregation at central inhibitory synapses (Kirsch et al., 1993). Using cultured rat spinal cord neurons, we demonstrate that clustering of the AMPA receptor subunit GluR1 is among the earliest events in excitatory synapse formation in vitro, coincident with the onset of miniature EPSCs and in many cases preceding pre- synaptic vesicle accumulation. Postsynaptic receptor clustering is induced in a highly specific and reiterative pattern, independent of receptor activation, by contact with a subset of axons capable of inducing receptor clusters. The subunit composition of AMPA receptor clusters varied significantly between neurons but was invariant within a given neuron. The presence of either GluR2 or GluR3 was common to all receptor clusters. Neither high-affinity glutamate transporters nor NMDA receptors appeared to be concentrated with AMPA receptor subunits at these excitatory synapses.

Key words: GluR1; synaptogenesis; spinal cord; glutamate transporter; glutamate receptors; rat; tissue culture
The molecular cloning of the family of glutamate receptors (GluRs), which mediate excitatory synaptic transmission in the CNS, has allowed the development of subunit-specific antibodies that hold promise for elucidating the mechanisms of GluR regulation during central synaptogenesis (Hollmann and Heinemann, 1994). The family of ionotropic GluRs comprise three classes. The first, termed AMPA receptors, includes the homologous subunits GluR1-4, which combine in varying heteromeric complexes to mediate fast, rapidly desensitizing, excitatory transmission. The termination of fast excitatory transmission occurs by either receptor desensitization or glutamate uptake (Trussell and Fischbach, 1989; Holmes, 1995), and high-affinity glutamate transporters from both neurons and glia have recently been cloned (Kanai and Hediger, 1992; Pines et al., 1992). The second class of GluRs, termed NMDA receptors, is formed from two distinct families: NR1, the presence of which is common to all NMDA receptors, and NR2A-D, which complex with NR1 to form functional channels (Kutsuwada et al., 1992; Sheng et al., 1994). The high calcium permeability and slow desensitization of the NMDA receptor are thought to mediate both electrical and second messenger signal transduction. A third class of ionotropic GluR, termed the kainate receptor, is composed of the subunits GluR5, 6, and 7, and KA1 and 2. The role of kainate receptors in synaptic transmission is unclear.

Work in vivo and in vitro using immunofluorescence and electron microscopy has shown that AMPA and NMDA receptors are concentrated at postsynaptic sites in dendritic spines (Petralia and Wenthold, 1992; Craig et al., 1993; Aoki et al., 1994; Huntley et

Received February 28, 1997; revised July 8, 1997; accepted July 14, 1997.

Correspondence should be addressed to Dr. Richard Huganir, Howard Hughes Medical Institute, PCTB 900, Johns Hopkins Medical School, 725 N. Wolfe Street, Baltimore, MD 21205.

Copyright (C) 1997 Society for Neuroscience $0270-6474 / 97 / 177339-12 \$ 05.00 / 0$ al., 1994; Baude et al., 1995; Lau and Huganir, 1995). The spinal cord in vitro is an attractive system for studying the regulation of GluRs during synaptogenesis, because excitatory synapses develop rapidly at sites of contact between axons and dendrites, with a resultant redistribution of glutamate chemosensitivity (O'Brien and Fischbach, 1986a; Trussell et al., 1988). The purpose of the present study is to follow the development of excitatory synapses on cultured neurons from the rat spinal cord, both electrically and immunohistochemically. We show that one of the earliest events in excitatory synapse formation is the clustering of postsynaptic AMPA receptors, which in the absence of appropriate synaptic input remain diffusely distributed. The subunit composition of postsynaptic AMPA receptor clusters varies considerably between neurons but is invariant within a given neuron. The signal for receptor clustering appears to be contact between appropriate axons and dendrites, and nearly all excitatory synapses are associated with postsynaptic receptor clusters. Presynaptic transmitter vesicles also accumulate rapidly but not necessarily synchronously with postsynaptic clusters. Surprisingly, neither NMDA receptors nor glutamate transporters were found to be clustered at excitatory synapses in cultured spinal neurons.

\section{MATERIALS AND METHODS}

Rat spinal cord cultures. Embryonic day (E) 18 or 19 rat ventral spinal cords were digested for $45 \mathrm{~min}$ at $34^{\circ} \mathrm{C}$ in L-15 media supplemented with $1 \mathrm{mg} / \mathrm{ml}$ papain, $1 \mathrm{~mm}$ kynurenic acid, $2 \mathrm{~mm}$ cysteine, $10 \mathrm{~mm}$ HEPES, and $2.5 \mathrm{~mm}$ EDTA according to the method of Huettner et al. (1986). Cells were gently dissociated with a $5 \mathrm{ml}$ pipette, filtered through a $70 \mu \mathrm{m}$ filter, and centrif uged through a solution of $1 \%$ soybean trypsin inhibitor and $1 \%$ BSA in L-15 at $80 \times g$ for $10 \mathrm{~min}$. Cells were then resuspended in media (see below) and plated at a density of 150,000 cells/60 mm dish. Each dish contained five glial-coated, $18 \mathrm{~mm}$ coverslips. Spinal cord glia were generated by dissociating and plating one postnatal day 2-4 rat spinal cord per $100 \mathrm{~mm}$ tissue culture dish in MEM supplemented with $10 \%$ horse serum, glutamine, pyruvate, and penicillin-streptomycin. The 
glia came to confluence over 2 weeks and were treated with $15 \mu \mathrm{g} / \mathrm{ml}$ 5 -fluorodeoxyuridine and $30 \mu \mathrm{g} / \mathrm{ml}$ uridine for $48 \mathrm{hr}$. Glial cultures were maintained in $5 \%$ horse serum for up to 2 months. Plates of glia were intermittently trypsinized in $0.05 \%$ trypsin $/ 0.05 \mathrm{~mm}$ EDTA, and plated onto collagen-derivatized glass coverslips (Aplin and Hughes, 1981) at 60,000 cells $/ 60 \mathrm{~mm}$ dish. Once glia were plated onto the coverslips, neurons were added within $72 \mathrm{hr}$. Growth media for neuronal cultures consisted of $75 \%$ MEM, 25\% Neurobasal Media (Life Technologies, Gaithersburg, MD), and N2 supplements, as described by Goslin and Banker (1991), as well as glutamine (2 mM), pyruvate (1 mM), penicillinstreptomycin, and $2 \%$ horse serum. All neuronal cultures were supplemented with $15 \mu \mathrm{g} / \mathrm{ml}$ E18 chick leg extract (Henderson et al., 1993). Forty percent of the media was changed every $72 \mathrm{hr}$. Under these conditions, plating efficiency was $70 \%$, and there was no significant cell loss for up to 3 weeks. High-density cultures for Western blotting were plated at 2 million cells $/ 60 \mathrm{~mm}$ dish. These dishes were coated with collagen and had a similar feeder layer of glia prepared in the days before the addition of neurons. High-density cultures otherwise were treated similarly to the low-density cultures. Spinal cord neurons grown in isolation on glial islands were prepared according to the technique of Segal and Furshpan (1990).

Electrophysiology. Recordings from spinal cord neurons were performed using standard whole-cell patch-clamp recording at a holding potential of $-60 \mathrm{mV}$. Extracellular solution consisted of $130 \mathrm{~mm} \mathrm{NaCl}, 4$ $\mathrm{mm} \mathrm{KCl}, 2 \mathrm{mM} \mathrm{CaCl} 2,1 \mathrm{~mm} \mathrm{NaH} \mathrm{PO}_{4}, 10 \mathrm{~mm}$ glucose, $12 \mathrm{~mm}$ HEPES, $10 \mu \mathrm{M}$ glycine, $200 \mu \mathrm{M}$ bicuculline, and $1 \mu \mathrm{M}$ strychnine, $\mathrm{pH}$ 7.3. The osmolarity of the extracellular solution was adjusted to 280 , and it was perfused over the neurons at a rate of $3 \mathrm{ml} / \mathrm{min}$ at $30^{\circ} \mathrm{C}$. Intracellular solution consisted of $115 \mathrm{~mm}$ potassium gluconate, $10 \mathrm{mM} \mathrm{KCl}, 2 \mathrm{~mm}$ MgATP, $1 \mathrm{~mm} \mathrm{CaCl}_{2}$, $11 \mathrm{~mm}$ EGTA, 10 mM HEPES, pH 7.3, 280 Osm. In some experiments neurobiotin (Vector Laboratories, Burlingame, CA) was included in the intracellular solution at $1 \mathrm{mg} / \mathrm{ml}$. NMDA, 20 $\mu \mathrm{M}$, was applied by rapid perfusion (Raymond et al., 1993) from a double-barreled pipette. Although routine recordings were performed in the absence of $\mathrm{Mg}^{2+}$ to maximize the ability to detect NMDA currents, control recordings of NMDA-gated currents in the presence of $\mathrm{Mg}^{2+}$ demonstrated typical voltage-dependent rectification. EPSCs were captured using PClamp6 software, and their amplitudes and time courses were analyzed using the simplex method of least squares fitting. All synaptic currents recorded under these conditions showed reversal potentials near $0 \mathrm{mV}$.

Immunohistochemistry. For standard immunohistochemistry, neuronal cultures were fixed in $4 \%$ paraformaldehyde, $4 \%$ sucrose in PBS for $30 \mathrm{~min}$, permeablized in $0.5 \%$ Triton $\mathrm{X}-100$, blocked in $10 \%$ goat serum at $30^{\circ} \mathrm{C}$ for $1 \mathrm{hr}$, and incubated with affinity-purified primary antibodies (see below) for $24 \mathrm{hr}$ at $4^{\circ} \mathrm{C}$. Rhodamine- or fluorescein-conjugated secondary antibodies (Jackson Immunochemicals, West Grove, PA) were then added at $10 \mu \mathrm{g} / \mathrm{ml}$ for $1 \mathrm{hr}$. Coverslips were mounted in Permafluor (Lipshaw) with $20 \mathrm{mg} / \mathrm{ml}$ Dabco (Aldrich, Milwaukee, WI). In cases in which two rabbit antisera were used, the first antiserum was incubated overnight, treated with FITCconjugated anti-rabbit antibody for $1 \mathrm{hr}$, washed extensively, and then incubated with $5 \%$ rabbit serum for $30 \mathrm{~min}$ at room temperature to saturate reactive ends on the secondary antibody. The second rabbit antiserum [usually anti-GluR1 primarily coupled to Cy3 (CyDye Kit, Amersham, Arlington Heights, IL)] was then added overnight in $5 \%$ rabbit serum. Control experiments consisted of incubating a $20 \times$ concentrate of either the first or second rabbit antibody with appropriate peptide $(0.2 \mathrm{mg} / \mathrm{ml})$ for $1 \mathrm{hr}$. This solution was then diluted 1:20 to its final concentration and added to the coverslips as above. In all cases, incubation of the primary antibody with appropriate peptide eliminated all dendritic staining. The affinitypurified anti-peptide antibodies used in this paper have been well characterized previously. GluR1, GluR2/3, and GluR4 (Blackstone et al., 1992) were used at $1 \mu \mathrm{g} / \mathrm{ml}$. The glial high-affinity glutamate transporter (GLT1) and the neuronal glutamate transporter (EAAC1) (Rothstein et al., 1994) were used at $0.2 \mu \mathrm{g} / \mathrm{ml}$ and $0.1 \mu \mathrm{g} / \mathrm{ml}$, respectively. A rabbit polyclonal anti-synapsin I antiserum (a gift of Dr. Paul Greengard, Rockefeller University) was used at a dilution of 1:2500. Monoclonal antibodies (mAbs) against synaptophysin $(0.4 \mu \mathrm{g} / \mathrm{ml})$, glutamic acid decarboxylase $(2 \mu \mathrm{g} / \mathrm{ml})$, gephyrin (mAb7a; $3 \mu \mathrm{g} / \mathrm{ml}$ ), and tau (mAb PC1C6; $10 \mu \mathrm{g} / \mathrm{ml}$ ) were purchased from Boehringer Mannheim (Indianapolis, IN). NR1 C-terminal antibody (Tingley et al., 1993) was used at $5 \mu \mathrm{g} / \mathrm{ml}$. An N-terminal antibody to NR1 was raised against the synthetic peptide RAACDPKIVNIGAVLSTRKHC and coupled to keyhole limpet hemocyanin (KLH) using maleimide-activated KLH (Pierce, Rockford, IL). This rabbit sera recognized a single $120 \mathrm{kDa}$ protein on immunoblots of cultured rat spinal cord.
For live cell staining, NR1 N-terminal antisera were added to complete culture medium at a dilution of 1:400 for $1 \mathrm{hr}$, rinsed three times in growth media, and then fixed as per our usual protocol. In transiently transfected HEK293 cells, this antisera resulted in specific, peptide-blockable staining of surface NR1 in live cells expressing a combination of NR1 and NR2A. All antisera and affinity-purified antibodies used in this study recognized single appropriately sized proteins on immunoblotting of spinal cord cultures (see below), and all dendritic staining could be blocked by preincubation with appropriate peptides as described above. Images were acquired on a Zeiss Axiophot microscope using either Ektachrome 1600 film at 800 ASA (see Figs. 2, 5, 8-10) or a Hamamatsu CCD camera using Image 1 software (see Figs. 4, 7).

Immunoblotting. Cell lysates from high-density cultures were solubilized in $1 \%$ Triton $\mathrm{X}-100,0.2 \%$ SDS and subjected to SDS-Page (7.5\% acrylamide). Proteins were transferred to Immobilon-P (Millipore, Bedford, MA), immunoblotted using the above-described antibodies at $\sim 0.5$ $\mu \mathrm{g} / \mathrm{ml}$, and visualized with enhanced chemiluminescence (Amersham).

\section{RESULTS}

\section{The development of GluR1 clusters correlates with the onset of EPSCs}

In cultures of rat ventral spinal cord, EPSCs can first be detected on day 3 in vitro and then gradually increase in frequency and distribution over the subsequent $7 \mathrm{~d}$ (Figs. 1, 3). By day 10, virtually all neurons display either continuous or bursting patterns of excitatory currents (Fig. $1 A$ ). These currents are completely abolished by low doses of the AMPA receptor antagonist CNQX (5 $\mu \mathrm{M})$ (Fig. 1B), and they exist, albeit at a lower frequency, in the presence of TTX $(1 \mu \mathrm{M})$ (Fig. $1 C)$, identifying them as classic miniature EPSCs (mEPSCs). When neurons were simultaneously filled with neurobiotin (Fig. $1 D$ ), most synapses, identified with the synaptic vesicle protein synaptophysin (Fig. $1 E)$, were seen to occur on neuritic shafts, although occasional synapses were seen on outpouchings that lacked the neck seen in true spines (Fig. 1D,E, arrowheads). Such morphology matches that seen in the spinal cord in vivo (Vaughn, 1989). Additionally, cultured spinal cord dendrites often had spike-like projections that lacked synapses (Fig. 1D, arrows). Consistent with their sensitivity to CNQX, mEPSCs seem to be derived almost exclusively from AMPA-type receptors. APV, a competitive inhibitor of NMDA receptors, had no clear effect on the amplitude or time course of synaptic currents. Additionally, in a series of 10 neurons, mEPSCs $(n=23)$, chosen for their rapid onset $(<0.7$ msec.), could be closely fitted (SD $<2 \%$ peak) with a single exponential, whose time constant for decay ranged from 0.8 to 4.0 msec (Fig. $1 F$ ). The lack of a slower synaptic component, consistent with NMDA receptor activation, was surprising given that all spinal neurons in which mEPSC analysis was conducted were sensitive to NMDA (Fig. $1 G$ ), with a mean peak amplitude of $390 \pm 120(\mathrm{SEM}) \mathrm{pA}$.

Paralleling the onset of excitatory synaptic currents, the GluR subunit GluR1 changed its distribution from diffuse to highly clustered (Figs. 2, 3). After 1 week in vitro, multiple GluR1 clusters (Fig. $2 C$ ) were seen on $70 \%$ of the neurons, and they coincided in almost all cases with the presence of presynaptic terminals, identified with the synaptic vesicle protein synaptophysin (Fig. 2D). Clustered GluR1 immunostaining appeared to be exclusively postsynaptic, because it was seen only in those neurons whose cell body was also GluR1 immunopositive, in agreement with previous work (Petralia and Wenthold, 1992; Craig et al., 1993; Baude et al., 1995; Kharazia et al., 1996). Fluorescent in situ hybridization (data not shown) showed a tight correlation between GluR1 immunostaining and mRNA expression and reconfirmed the localization of GluR1 clusters, seen immunohistochemically, to the dendrites of neurons expressing GluR1 mRNA. 


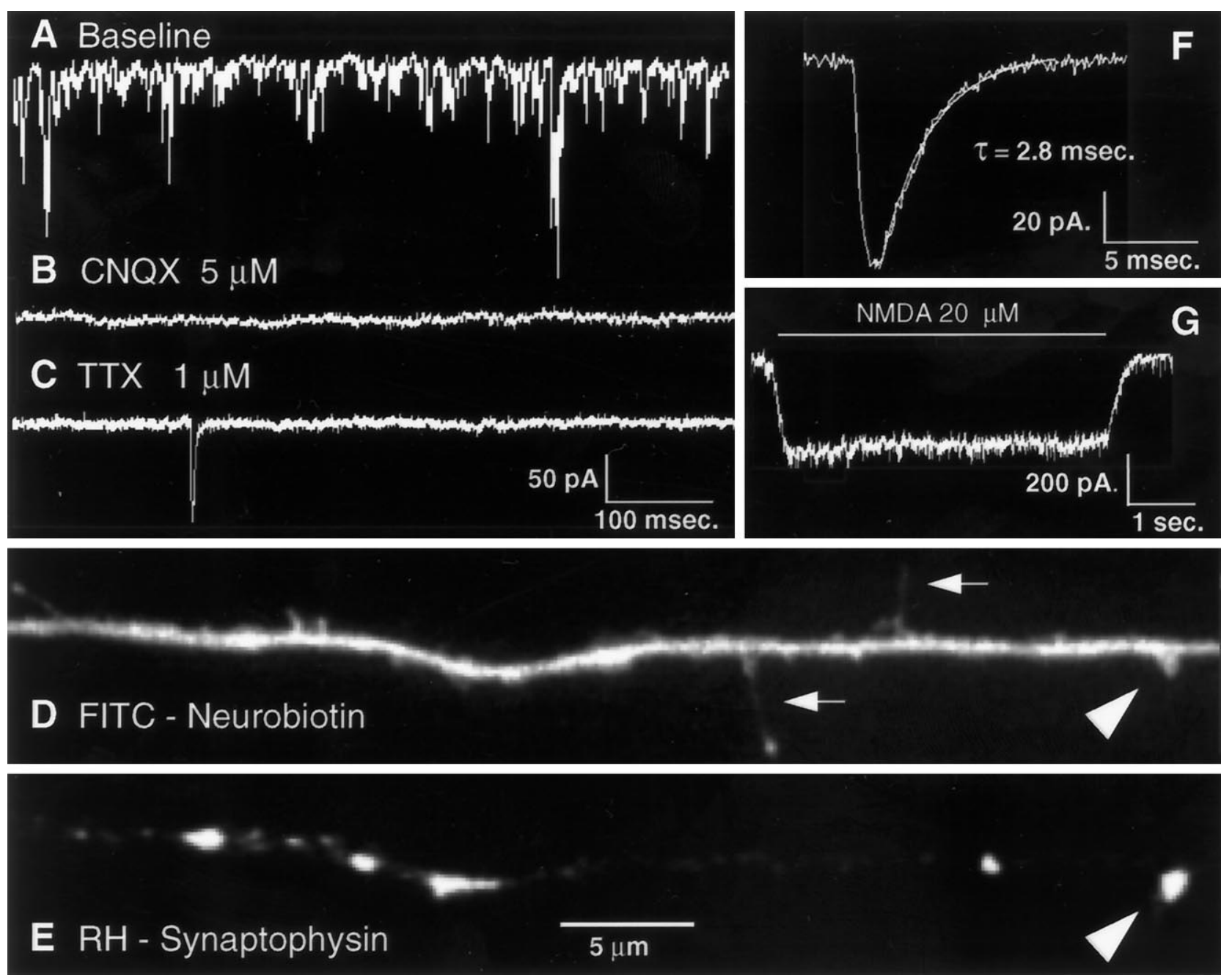

Figure 1. Synaptic currents in cultured spinal cord neurons. At $11 \mathrm{~d}$ in vitro, baseline recording at $30^{\circ} \mathrm{C}$ with a holding potential of $-60 \mathrm{mV}$ reveals continuous excitatory synaptic activity in spinal cord neurons $(A)$ that is completely blocked by CNQX $(B)$. The same cell was filled with neurobiotin and stained with FITC streptavidin and rhodamine anti-synaptophysin in $D$ and $E$ to reveal synapses (synaptophysin clusters) only on shafts and occasional dendritic outpouchings (arrowheads in $D, E$ ). Spike-like projections, which were seen in many but not all neurons, were devoid of synapses (arrows in $D$ ). In $C$ and $F$, synaptic currents are recorded from a second neuron in the presence of $1 \mu \mathrm{M}$ TTX, a concentration sufficient to eliminate all regenerative sodium currents. These mEPSCs are easily fitted with a single exponential for decay $(F)$. The same neuron was later tested for sensitivity to $\operatorname{NMDA}(G)$.

\section{Correlation of GluR1 clusters with excitatory nerve terminals}

Although all GluR1 clusters on mature neurons were associated with presynaptic specializations in the form of synaptic vesicle accumulation, many synaptic terminals on GluR1-immunopositive neurons were not associated with GluR1 clusters (Fig. 2D, arrows). It was our initial assumption that these latter sites represented inhibitory synapses; however, given the recent interest in the possibility of dormant or "silent" excitatory synapses (Isaac et al., 1995), we believed it necessary to determine whether these synapses represented a large pool of excitatory synapses without associated postsynaptic receptor clusters. Data from the rat spinal cord in vivo has indicated that inhibition in the ventral cord is mediated by both glycine and GABA (Triller et al., 1987; Todd et al., 1995), although precise quantitative distributions of the two are lacking. Our preliminary work had indicated that staining with antibodies to gephyrin, a $93 \mathrm{kDa}$ postsynaptic protein associated with both glycinergic and to a lesser extent GABAergic synapses (Kirsch et al., 1993), and glutamate decarboxylase (GAD), an enzyme associated with presynaptic GABAergic terminals (Oertel et al., 1984), resulted in discreet pre- and postsynaptic clusters, respectively. Nearly all neurons had postsynaptic gephyrin clusters, whereas fewer had presynaptic terminals that stained with GAD (data not shown). On the whole, gephyrin clusters outnumbered GAD terminals by $\sim 2$ to 1 . We found minimal overlap between these two markers of inhibitory synapses and GluR1 staining. Using a triple stain technique (Fig. 4), we quantitatively analyzed synaptic identity in a series of eight digitized neurons after $10 \mathrm{~d}$ in vitro. Synaptic terminals were identified with AMCA-labeled synapsin, AMPA receptor clusters were identified with Cy3-labeled GluR1, and inhibitory synapses were identified with a combination of FITC-labeled GAD (GABAergic) and FITC-labeled gephyrin (glycinergic). A total of 165 synapses were identified (Fig. 4A), of which $153(93 \%)$ had either a GluR1 cluster (42\%) (Fig. $4 B)$ or a GAD/gephyrin cluster (51\%) (Fig. 4C). Of the 153 synapses, 6 had overlapping clusters of GluR1 and GAD/gephyrin. Thus, nearly all synaptic release sites not associated with GluR1 clusters can be accounted for by inhibitory synapses, making postsynaptic receptor 

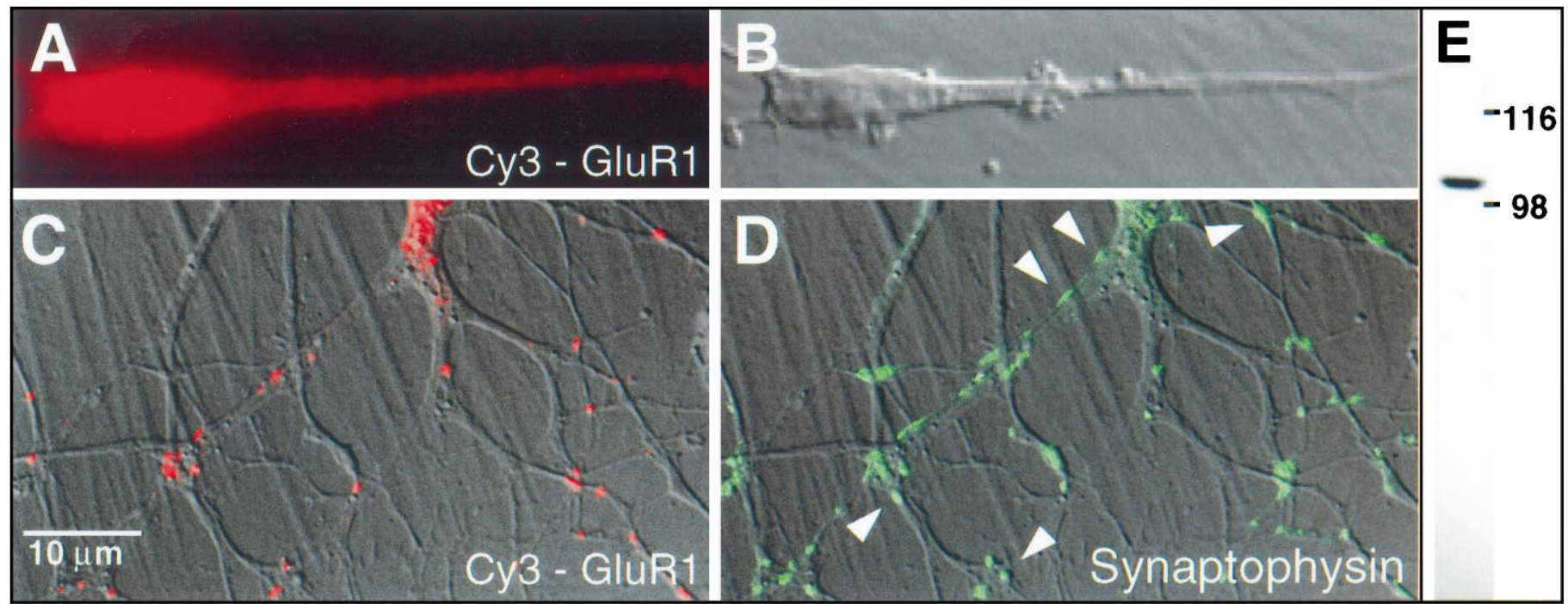

Figure 2. Clustering of the AMPA receptor subunit GluR1. Fixed and permeablized spinal cord neurons were stained with a C-terminal antibody against GluR1 at $2(A)$ and $11(C) \mathrm{d}$ in vitro. The diff use pattern originally seen on day 2 is transformed into a highly clustered pattern by day 11 , only at sites of synaptic contact between cells, defined by the presence of presynaptic synaptophysin stain $(D)$. Selected synaptophysin clusters not associated with GluR1 clusters are designated with arrowheads. In $E$, an immunoblot of the C-terminal GluR1 antibody against 11 day cultured spinal cord neurons is shown, with a single protein at the appropriate size for GluR1. Cy3 and Nomarski images were superimposed at a 70:30 ratio in $C$ and a 50:50 ratio in $D$ using Adobe Photoshop.

Figure 3. Correlation of GluR1 clustering and synaptic currents. A series of spinal cord neurons were stained with GluR1 at the designated times in culture. Simultaneously, additional neurons were assayed for the presence or absence of spontaneous excitatory synaptic activity. Each cell was scored for the number of GluR1 clusters within the first $60 \mu \mathrm{m}$ of each major dendrite, as well as for the presence or absence of staining at the cell body. Each physiology time point represents 15 neurons from three different platings $(3 \times 5)$, and each immunohistochemical time point represents at least 50 neurons from three separate platings. Values for immunohistochemistry are expressed \pm SEM. Continuous EPSCs (such as seen in Fig. 1A) are plotted as an indication of the increasing frequency of excitatory synaptic currents.

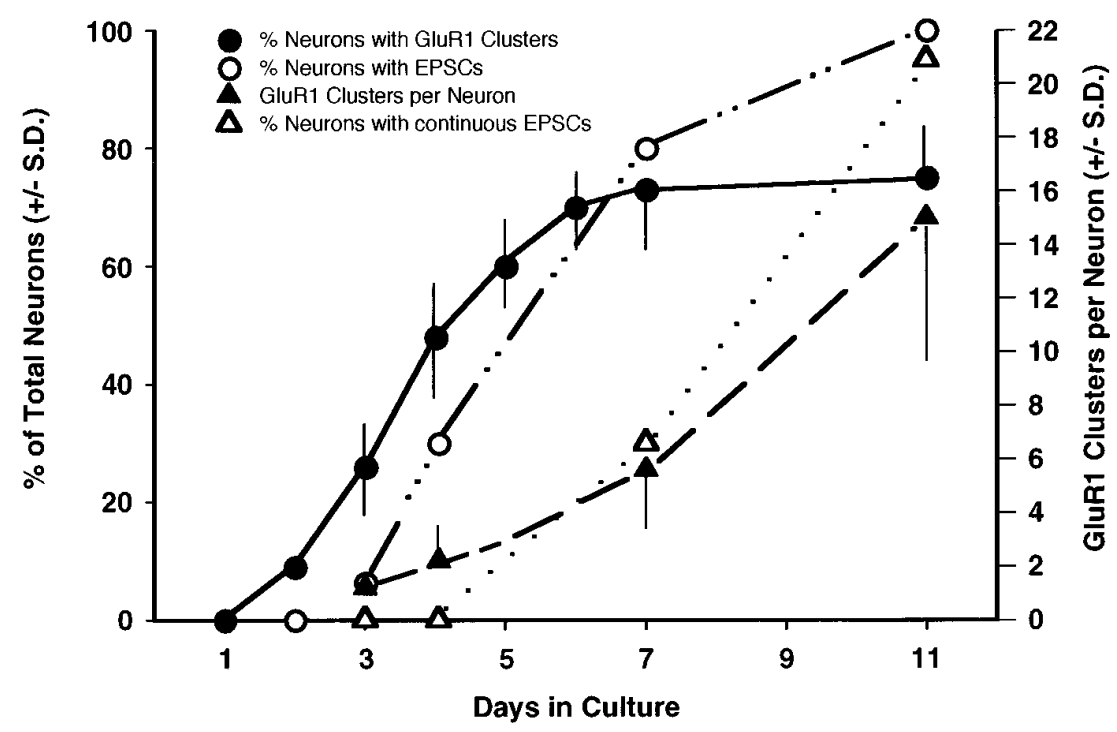

clustering a near-universal property of excitatory synapse formation in cultured spinal neurons.

\section{GluR1 clustering in isolated neurons}

To further study the specificity of AMPA receptor clustering, and to investigate the distribution of GluR1 in the absence of appropriate synaptic input, individual spinal cord neurons were grown for 8-10 d on glial islands, forcing them to form homogeneous autaptic connections. Under these circumstances neurons can be neatly divided into those that induce clusters of GluR1 at every synapse and those that do not. As shown in Figure 5, a total of 84 solitary neurons grown on islands of glia were studied, of which 64 were GluR1 immunopositive and were analyzed further. Twenty $(31 \%)$ of the 64 showed a near-complete correlation between synaptophysin clusters $(n=154)$ and GluR1 clusters $(n=149)$ (Fig. $5 A), 25$ neurons (40\%) had multiple synaptophysin clusters
( $n=122)$ but no GluR1 clusters (Fig. $5 B)$, and the remaining 19 neurons had neither GluR1 clusters (even though they were GluR1 immunopositive) nor synaptophysin clusters. Given that all GluR1-immunopositive neurons in mixed spinal cord cultures have GluR1 clusters (Fig. 3), these experiments demonstrate that in the absence of appropriate synaptic input, the AMPA receptor subunit GluR1 remains diffusely distributed.

A second series of experiments confirmed the specificity of cluster induction. Twenty-seven solitary R1-immunopositive neurons were stained for GAD immunoreactivity: nine were GAD positive and had no GluR1 clusters, 10 had GluR1 clusters and were GAD negative, and eight had neither GluR1 clusters nor GAD staining (data not shown). In sum, these experiments support the claim that $\sim 30 \%$ of the ventral spinal cord neurons that grow under these conditions are capable of inducing clusters of 


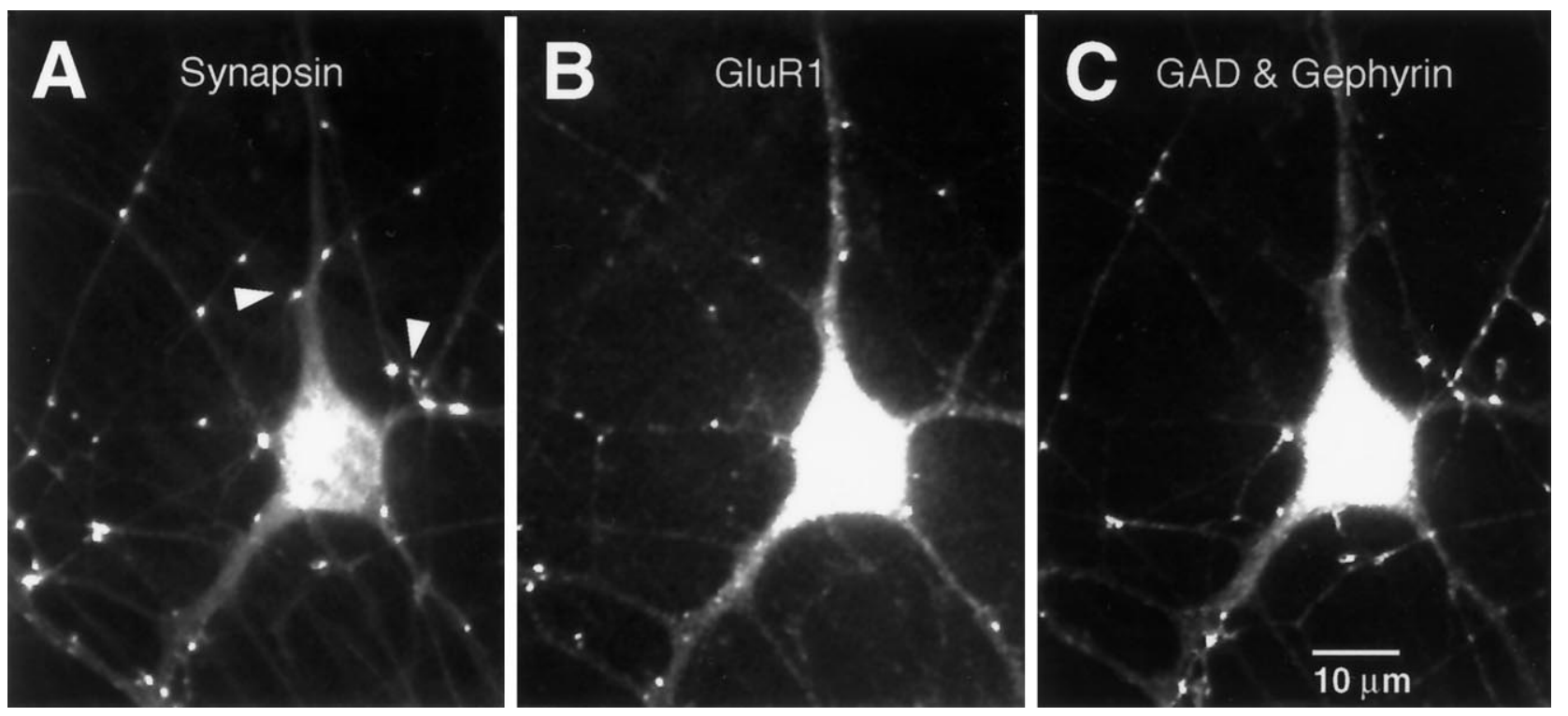

Figure 4. Analysis of synaptic identity. After $10 \mathrm{~d}$ in culture, spinal cord neurons were fixed and stained with rabbit anti-synapsin (1:2500), mouse anti-GAD $(2 \mu \mathrm{g} / \mathrm{ml})$, and mouse anti-gephyrin (1:150). Secondary antibodies consisting of AMCA anti-rabbit and FITC anti-mouse were then added. Finally, Cy3-GluR1 was added as described in Materials and Methods. A series of eight GluR1-positive neurons were digitized using three different excitation wavelengths to distinguish synapsin (AMCA; Fig. 6A), GluR1 (Cy3; Fig. 6B), and GAD/gephyrin (FITC; Fig. 6C). Almost all synapses (synapsin clusters) can be accounted for either by inhibitory synapses (GAD/gephyrin) or GluR1 clusters. Two synapses with neither GluR1 nor GAD/gephyrin staining are identified in $A$ (arrowheads).
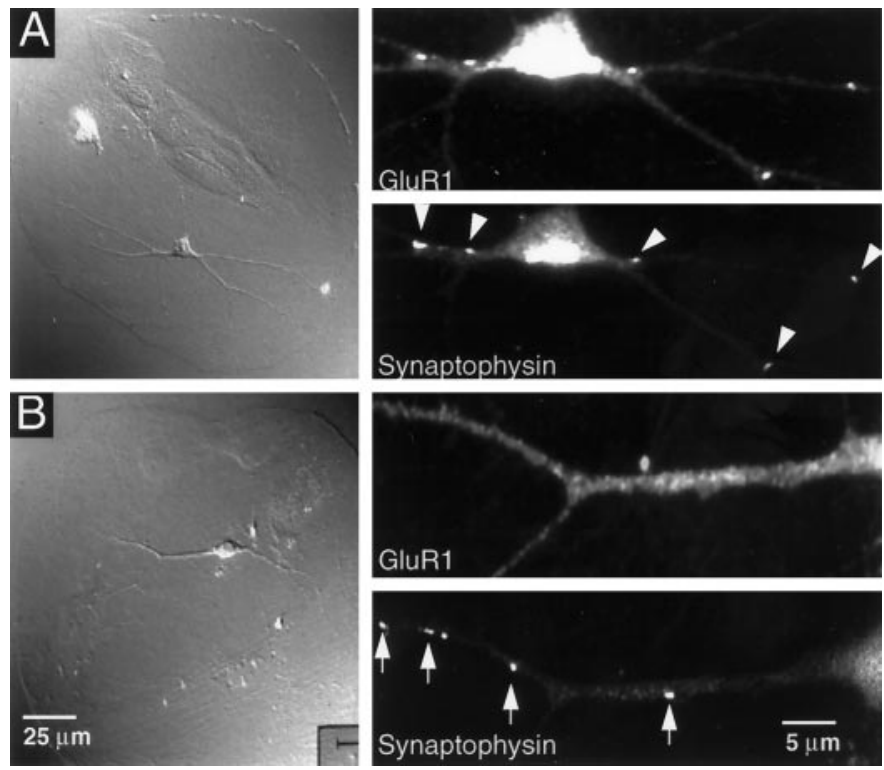

Figure 5. GluR1 clusters in island cultures. Solitary neurons growing on islands of glia were analyzed for GluR1 staining and synaptophysin clusters. Neurons could be divided into those that did $(A)$ or did not $(B)$ form GluR1 clusters at each synapse. Synapses are designated with arrowheads in $A$ and arrows in $B$. Neurites were not seen to extend from one island to another across the agarose barrier.

postsynaptic GluR1 at each synaptic contact with a GluR1expressing neuron. This contact results in a reciprocal accumulation of transmitter vesicles in the presynaptic neuron.

\section{The maturation of presynaptic terminals at sites of GluR1 clustering}

Although mature excitatory synapses in cultured spinal cord neurons displayed a tight correlation between presynaptic vesicle accumulation and postsynaptic receptor clusters, such was not true for early contacts. As shown in Figure 6, the usual pattern of intense staining for the synaptic vesicle proteins synaptophysin (Fig. 6A,B) or synapsin 1 (Fig. 6C,D) was absent at nearly half the GluR 1 clusters seen on days 2 and 3 in vitro (Table 1 ). These early receptor aggregates do not represent spontaneous receptor clustering such as seen in cultured myotubes (Anderson and Cohen, 1977; Frank and Fischbach, 1979), because none were seen in uninnervated island cultures (see above) and because all occurred at sites of cell-cell contact, determined either visually $(6 A, B)$ or with staining for the axon-specific microtubule-associated protein tau (Fig. 6E). During the first $72 \mathrm{hr}$ in culture, a time at which nearly $50 \%$ of the GluR1 clusters were not associated with significant reciprocal presynaptic vesicle accumulation, 112 of 118 consecutive GluR1 clusters, seen in two separate platings, occurred when a neurite strongly immunopositive for tau contacted a GluR1-expressing dendrite (Fig. 6D,E). In contrast, the GluR1expressing process stained much more lightly for tau. These results show not only that GluR1 clustering occurs only at sites of cell-cell contact, but also that only processes that stain strongly for tau (i.e., axons) express the molecules capable of inducing cluster formation. The ability of these axons to induce postsynaptic clusters often occurs in the absence of complete presynaptic maturation, given the paucity of synaptic vesicles at many of these early contacts.

Consistent with the lack of significant synaptic vesicle accumulation at many early receptor clusters, we saw no evidence that AMPA or NMDA receptor activation played a role in receptor clustering. Craig et al. (1994) reported that chronic incubation of hippocampal cultures with TTX did not prevent the formation of AMPA receptors clusters. We have also observed that TTX was without effect on GluR1 clustering in rat spinal cord cultures. Given the existence of mEPSCs, which are resistant to TTX, however, we performed a series of experiments to ensure that TTX-resistant mEPSCs do not contribute to receptor clustering. 

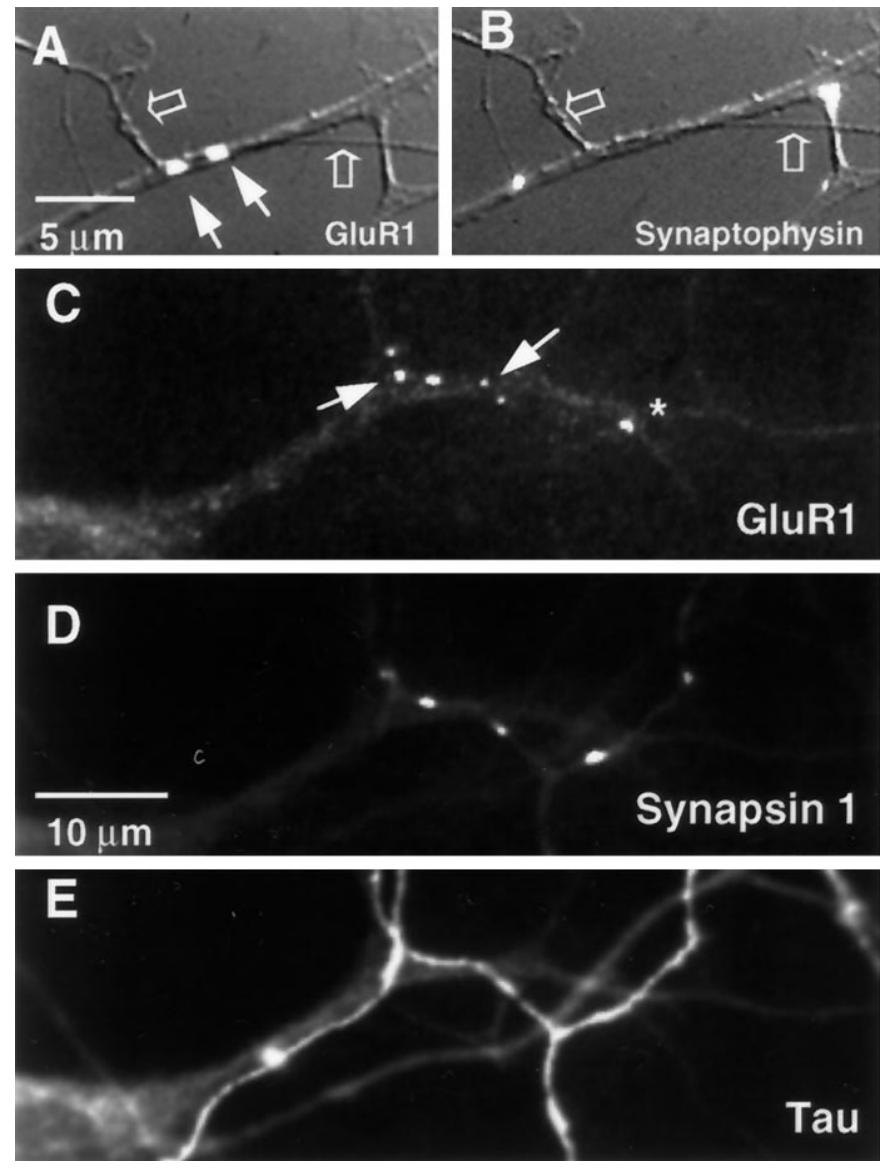

Figure 6. Synaptic vesicle accumulation at newly formed synapses. In $A$ and $B$, fluorescent images are superimposed on Nomarski images at a ratio of 70:30 (Cy3-GluR1) and 50:0 (FITC-synaptophysin) to demonstrate the induction of GluR clusters by cell-cell contact. In $A$ and $B$, a day 3 neurite capable of clustering GluR1 is designated by open arrows as it crosses a GluR1-expressing dendrite, inducing two clusters of GluR1 $(A$, closed arrows) devoid of synaptophysin stain $(B)$. Nearby synaptophysin stain serves as a positive control. In $C-E$, two day 3 axons stained with tau $(E)$ contact a GluR1-expressing neuron inducing six clusters of GluR1 $(C)$, two of which are devoid of associated synapsin 1 stain $(C$, arrows $)$ and one of which is displaced from a nearby cluster of vesicles $(C$, asterisk $)$. In the majority of cases, a complete lack of associated presynaptic vesicle accumulation was seen rather than a physical displacement.

Table 1. Percentage of GluR1 clusters associated with synaptic vesicle protein accumulation

\begin{tabular}{lllll} 
& Day 2 & Day 3 & Day 4 & Day 6 \\
\hline Synaptophysin + & $56 \%(32 / 57)$ & $70 \%(51 / 73)$ & $91 \%(43 / 47)$ & $97 \%(80 / 82)$ \\
Synapsin 1+ & $47 \%(19 / 40)$ & $62 \%(49 / 78)$ & $83 \%(43 / 52)$ & $91 \%(47 / 52)$
\end{tabular}

$\overline{\text { Consecutive clusters of GluR1 were categorized in a series of two separate platings }}$ as either associated or unassociated with presynaptic staining for the synaptic vesicle proteins synaptophysin or synapsin 1, as described in Materials and Methods. A lack of synaptic vesicle accumulation could be attributable to either a complete absence of nearby synaptic vesicles (the majority of cases) or a clear misalignment of postsynaptic clusters and presynaptic vesicles (see Fig. 6 for examples). Cultures stained for synapsin 1 were also stained with an antibody to tau to identify the presence of axons at these early GluR1 clusters.

Spinal cord cultures were treated with $0.5 \mathrm{~mm}$ APV, $20 \mu \mathrm{M}$ CNQX, and $2 \mu \mathrm{M}$ TTX in a complete change of media every 48 hr for the first $6 \mathrm{~d}$ in culture. Control cultures had similar media changes without inhibitors. After $6 \mathrm{~d}$ in vitro the number of neurons with GluR1 clusters and the number of GluR1 clusters per neuron were identical in the control $[4.7 \pm 1.4(\mathrm{SEM}) ; n=56]$ and treated cultures $(5.2 \pm 1.0 ; n=63)$. To ensure that the inhibitors were maintaining their potency for the full $48 \mathrm{hr}$ in vitro, we tested several batches of media for its ability to completely block spontaneous mEPSCs after $2 \mathrm{~d}$ in culture. In every case $(n=3)$ there was complete suppression of both action potentials and mEPSCs.

\section{Coexpression of multiple AMPA receptor subunits}

In addition to GluR1, cultures of rat ventral spinal cord express the AMPA receptor subunits GluR2/3 and GluR4, both by immunoblotting and immunocytochemistry. For the purposes of this study, GluR2 and GluR3 are referred to as a single entity, because our antibody recognizes the 20 amino acid $\mathrm{C}$ terminus common to both. Immunostaining for GluR2/3 is present in all neurons tested to date and is seen from the earliest time points. In 38 neurons that expressed both GluR1 and GluR2/3, GluR1 clusters were seen to clearly colocalize with GluR2/3 clusters in 171 of 174 cases (Fig. $7 C$ ). In addition to colocalization, the relative intensities of the signals from GluR1 and GluR2/3 appeared similar at different synapses within a given neuron. Even at the very earliest time points (Day 3), when clusters of GluR1 and excitatory synapses can first be detected, GluR2/3 staining was clearly seen to colocalize with GluR1 clusters (Fig. 7A), except for occasional instances (Fig. $7 B$, arrow) when high dendritic background staining made the detection of GluR2/3 clusters difficult. Coimmunoprecipitation experiments confirm the association between GluR2/3 and GluR1 as early as day 4, the first time at which GluR1 or GluR2/3 can be reliably immunoprecipitated (data not shown). In the $30 \%$ of neurons in which GluR1 was not expressed (Fig. 7D), clusters of GluR2/3 had an appearance, distribution, and number identical to those in neurons expressing GluR1, and they were always associated with presynaptic synaptophysin stain after $7 \mathrm{~d}$ in culture.

GluR4 was expressed in a pattern somewhat different from either GluR1 or GluR2/3. First, GluR4 was not detectable by immunohistochemistry or Western blot until 1 week in culture, by which time excitatory synapses were well established. In addition, specific staining for GluR4 was also present in glial cells, as has been described previously (Petralia and Wenthold, 1992; Martin et al., 1993). After 1 week in vitro, most neurons still lacked GluR4 (Fig. $8 A$ ), but the population of neurons that expressed both GluR1 and GluR4 ( 20\%) displayed colocalization of clustered GluR4 with GluR1 clusters in almost all cases (Fig. 8B). A small fraction of neurons immunonegative for GluR1 expressed clusters of GluR4 that were similar in appearance to neurons expressing GluR1 (Fig. 8C).

Because our previous experiments with tau immunostaining and neurobiotin injection had suggested that each cultured spinal cord neuron receives excitatory synaptic input from several other neurons, these results suggest that once spinal neurons express an AMPA receptor subunit, that subunit is expressed at all its excitatory synapses regardless of the source of synaptic input. In none of the neurons examined to date was there a suggestion that AMPA receptor subunit composition could vary within a postsynaptic neuron at sites of varying presynaptic input; however, because we are dealing with a rather homogeneous population of cells, it is possible that a more divergent source of synaptic input such as dorsal root ganglion cells could alter this interpretation. GluR2/3 is the only AMPA receptor subunit common to all excitatory synapses in all cultured spinal neurons. 


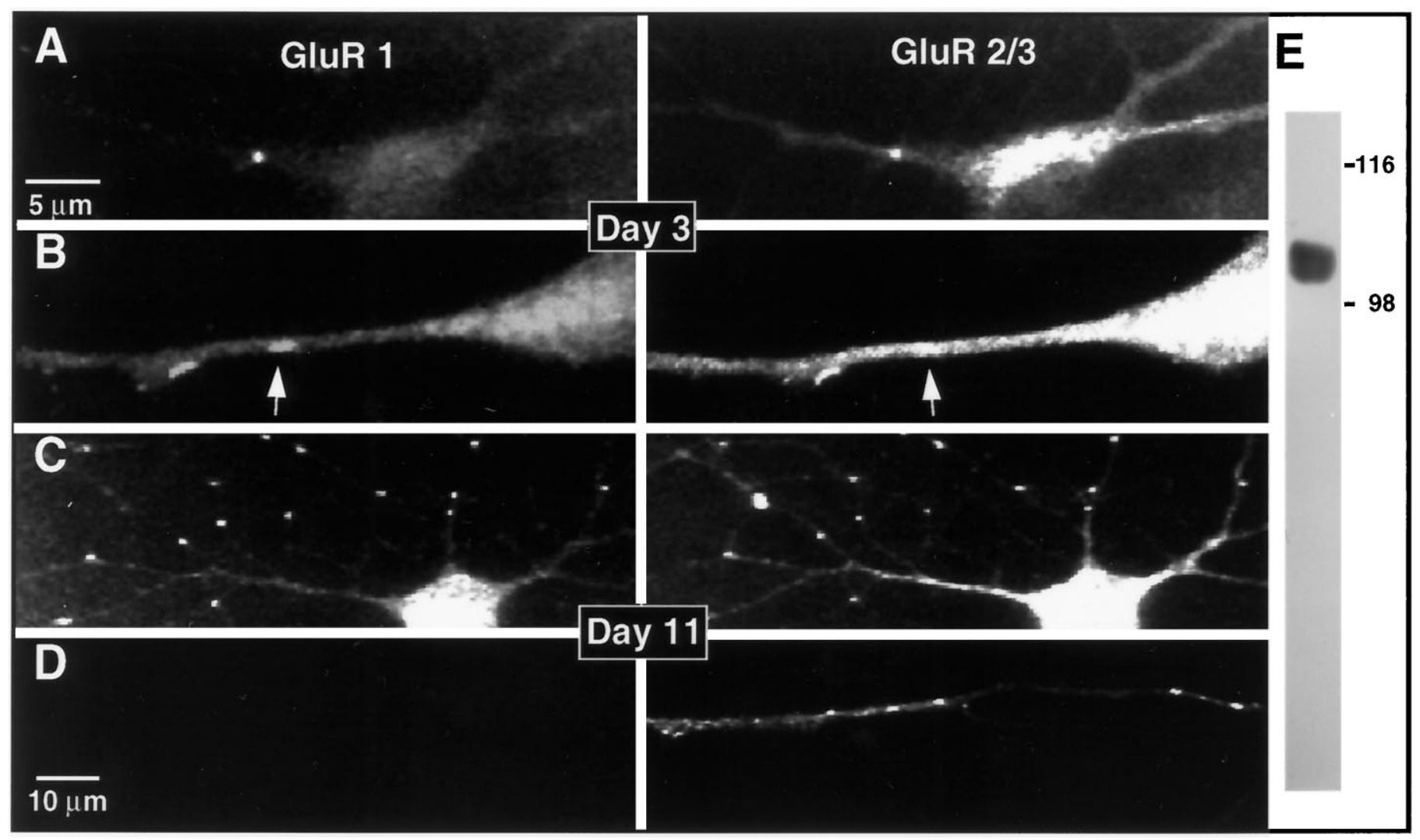

Figure 7. Colocalization of GluR1 and GluR2/3. Neurons were fixed, permeablized, and double-labeled with antibodies against GluR1 and GluR2/3 as described in Materials and Methods. Although most early clusters showed clear colocalization of GluR1 and GluR2/3 ( $A$, $B)$, occasional GluR2/3 clusters were difficult to colocalize with GluR1 clusters because of high generalized dendritic stain (B, arrows). By Day 11, all GluR1 clusters clearly colocalized with GluR2/3 $(C)$. In the $30 \%$ of neurons without GluR1 clusters, GluR2/3 clusters $(D)$ had an appearance similar to those in neurons expressing GluR1. In $E$, a Western blot of GluR2/3 against spinal cord cultures demonstrates a single, appropriately sized band. The size calibration in $A$ applies to $A$ and $B$; the size calibration in $D$ applies to $C$ and $D$.

\section{The NMDA receptor subunit NR1 is not clustered at excitatory synapses}

As mentioned previously, mEPSCs in cultured rat spinal neurons are composed predominantly of AMPA-type receptor currents, despite the presence of electrophysiologically active NMDA channels. We investigated the immunohistochemical distribution of NR1, a subunit common to all NMDA receptors, using both Cand N-terminal antibodies, and compared it with the distribution of GluR1 in the same neurons. In all cells investigated, for periods up to 3 weeks in culture, NR1 staining was diff use, without any relation to GluR1 or synaptophysin clusters. As shown in Figure 9, staining with both the C-terminal antibody (Fig. $9 A$ ), which in fixed and permeablized cells detects the entire pool of NR1, and the N-terminal antibody (Fig. 9C), which when applied to live cells detects the surface pool of NR1, failed to reveal any significant clustering of NR1 and showed no colocalization with GluR1 clusters (Fig. 9B,D). A similar diff use staining pattern was seen with the well-characterized mouse mAb 54.1 (Huntley et al., 1994), which is specific for the region between TM3 and TM4 of NR1 (data not shown). Although we visualized no clustered NR1 with our panel of antibodies, we believe that the diff use staining pattern seen for NR1 reflects the true distribution of NR1, for several reasons. First, the diffuse staining pattern was seen with three different antibodies made to distinct regions of NR1. This pattern might be expected given the electrophysiological results. Second, the staining pattern appeared specific, in that no glial cells were stained by any antibody (there is a diffuse mat of glia underlying the neurons photographed in Fig. 9). Finally, all three antibodies gave similar staining patterns and intensities in HEK293 cells transfected with combinations of NR1 and NR2A.

\section{The distribution of neuronal and glial glutamate transporters in spinal cord cultures}

Antibodies directed against the intracellular $\mathrm{C}$ terminus of both the neuronal and glial high-affinity glutamate transporters were used to stain cultures of rat spinal cord. Specific immunostaining for EAAC1 was distributed diff usely in the dendrites of all ventral spinal cord neurons for periods of up to 4 weeks in vitro (Fig. $10 C)$. Although occasionally micropunctate, there was no correlation of transporter staining with postsynaptic GluR1 clusters (Fig. 10B). Although all GluR1-expressing dendrites stained for EAAC1, most presumptive axons (slender, unbranched, GluR1negative processes ending in synapses) (Fig. 10 A, arrows) and glia were unstained. In addition, because excitatory presynaptic terminals correlate with GluR1 clusters, these observations exclude a significant accumulation of glutamate transporter in presynaptic terminals. GLT1 was present in $\sim 50 \%$ of the glial cells in our cultures and when present stained in a diffuse pattern. In Figure $10 \mathrm{E}$, the central immunopositive glial cell is surrounded by glial cells that remain unstained. A neuron expressing multiple clusters of GluR1 lies on top of the GLT1-expressing glial cell (Fig. 10E, boxed area). That neuron, stained for GluR1, and the correspond- 

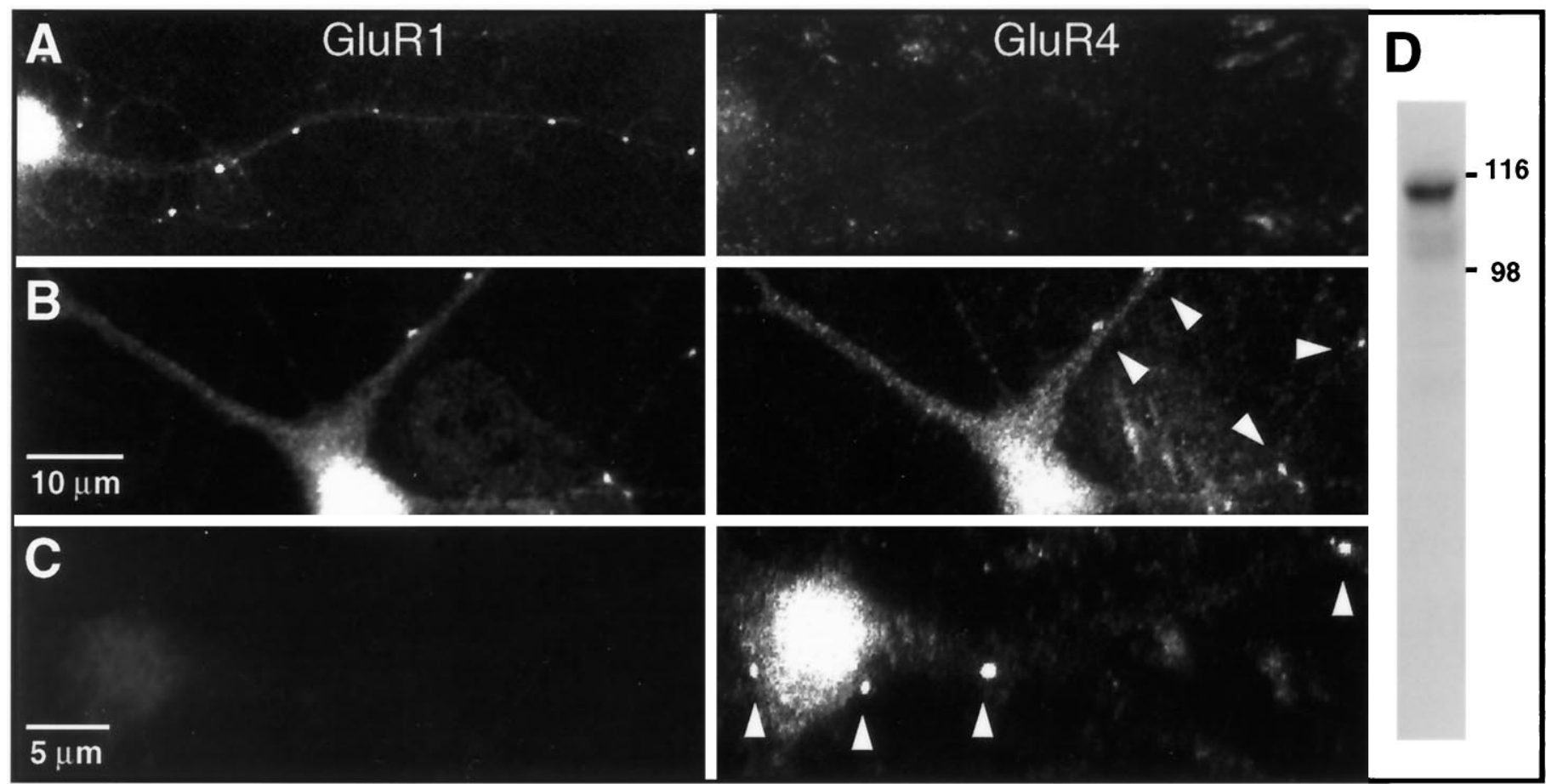

Figure 8. Colocalization of GluR1 and GluR4. As in Figure 7, neurons were double-labeled with antibodies against GluR1 and GluR4 after 8 d in culture. In a series of 85 neurons, 43 showed the pattern in $A(\mathrm{R} 1+/ \mathrm{R} 4-), 15$ showed the pattern in $B(\mathrm{R} 1+/ \mathrm{R} 4+)$, and 6 showed the pattern in $C$ $(\mathrm{R} 1-/ \mathrm{R} 4+)$. In all neurons in which both GluR1 and GluR4 were expressed, a similar proportion of GluR1 and GluR4 was present at each synapse (B). Selected R4 clusters are designated with arrowheads. An immunoblot of GluR4 against cultured spinal cord neurons is shown in $D$, with a single, appropriately sized protein. The calibration in $B$ applies to $A$ and $B$.
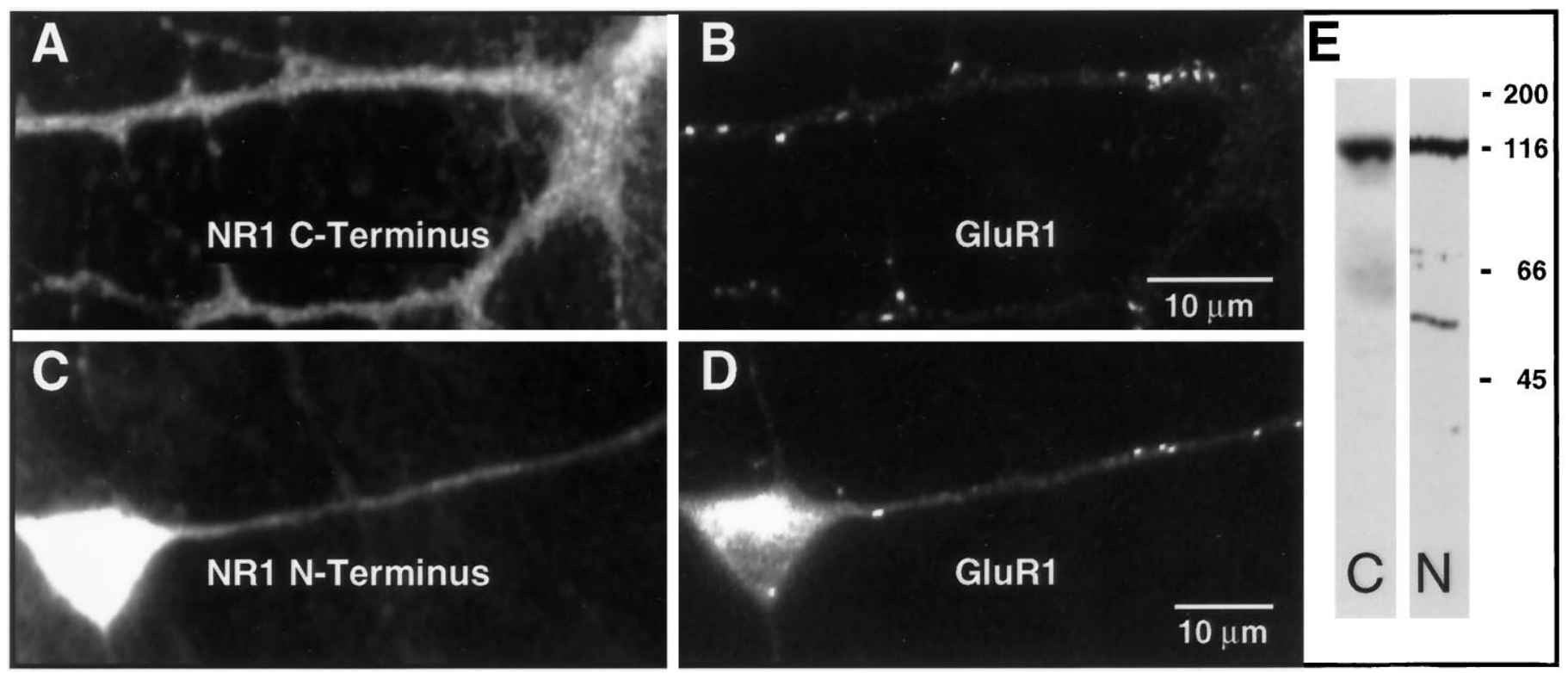

Figure 9. Localization of NR1 in spinal cord neurons. C-terminal antibodies to NR1 were used in fixed and permeablized spinal cord cultures (Fig. $10 A)$ as described in Materials and Methods. N-terminal antibodies were added to live cultures for $1 \mathrm{hr}$, rinsed three times in media, and then processed as described in Materials and Methods (Fig. 10C). There was no evidence of significant NR1 clustering with either the C-or N-terminal antibody, and no correlation of NR1 staining with GluR1 clusters (compare Fig. $10 A$ with $B$, and $10 C$ with $D$ ). Note is also made that the background layer of glial cells, which is confluent under our conditions, is unstained with either the C- or N-terminal NR1 antibody, or with the GluR1 antibody. In $E$, immunoblots of spinal cord cultures with affinity-purified $\mathrm{C}$-terminal $(C)$ and N-terminal $(N) \mathrm{NR} 1$ antibodies are shown. Each shows a major protein at $116 \mathrm{kDa}$, the approximate size of NR1. 

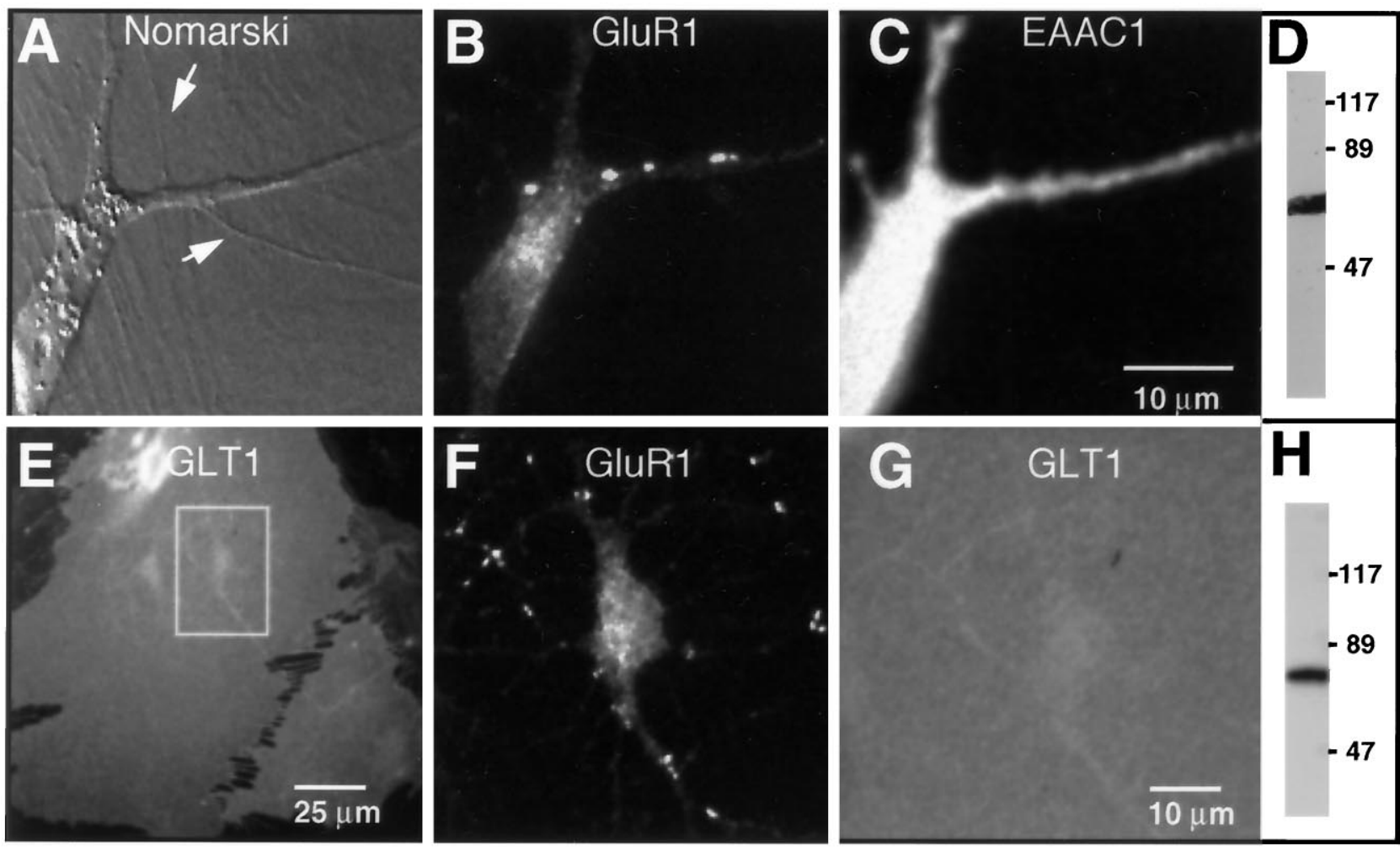

Figure 10. Distribution of glutamate transporters in cultured spinal cord cells. Spinal cord cultures were double-labeled with antibodies against GluR1 $(B, F)$ and either EAAC1 $(C)$ or GLT1 $(E, G)$. The Nomarski image in $A$ corresponds to images in $B$ and $C$ and is shown to illustrate the presence of presynaptic axons (arrows), which do not stain with EAAC1. In $E$, a low-power photomicrograph of GLT1 staining is included to demonstrate that only some glia stain for GLT1 (at these times in culture, the glial monolayer is confluent, including all the dark areas in $E$ and $>90 \%$ stain for GFAP). The boxed area in $E$ is shown at higher magnification in $F$ (GluR1) and $G$ (GLT1) to demonstrate the lack of clustered glial transporter. Immunoblots of spinal cord cultures incubated with antibodies to EAAC1 and GLT1 are shown in $D$ and $H$, respectively. Each demonstrates a single, appropriately sized protein. The scale bar shown in $C$ applies to $A-C$; the scale bar in $G$ applies to $F, G$.

ing area of the glial cell, stained for GLT1, are shown at higher magnification in Fig. 10, $F$ and $G$, respectively, to demonstrate the lack of clustered GLT1 staining at excitatory synapses in these cultures. We were not able to detect any specific immunostaining with antibodies to the less widely distributed glial transporter GLAST.

\section{DISCUSSION}

\section{The development of AMPA receptor clusters during synaptogenesis}

In cultures of rat spinal cord there exists a population of neurons, comprising $30 \%$ of those grown on glial islands, that are capable of inducing clusters of the AMPA receptor subunit GluR1 each time they form a synaptic connection with a GluR1-expressing dendrite. Clustering of postsynaptic receptors appears to be a nearly universal component of excitatory synaptogenesis in these cultures. In the absence of appropriate input, AMPA receptors are expressed but remain diffusely distributed. Although the onset of GluR1 clustering coincides with the first signs of spontaneous excitatory transmission, the activation of postsynaptic excitatory neurotransmitter receptors appears to play no role in the development of GluR1 clusters. The same cell-cell interaction that results in postsynaptic AMPA receptor clustering also results in a rapid, but not necessarily synchronous, accumulation of presynaptic vesicles. The induction of GluR clusters during synaptogenesis correlates well with previous studies of glutamate chemosensitivity in cultured neurons from the spinal cord and hippocampus (O'Brien and Fischbach, 1986b; Jones and Baughman, 1991), which showed that the development of focal areas of increased chemosensitivity was dependent on synaptic input. Studies of the distribution of $\mathrm{GABA}_{\mathrm{A}}$ (Killisch et al., 1991) and glycine receptors (Bechade et al., 1996) in cultured neurons also suggest that an initially diffusely distributed population of receptors becomes restricted to synaptic contacts over time. Unlike the neuromuscular junction, however, in which the synaptic accumulation of acetylcholine receptors involves the aggregation of preexisting surface receptors (Bowe and Fallon, 1995) as well as the localized insertion of newly formed receptors (Falls et al., 1993), there is as yet little information on the pool from which synaptic receptors are derived in the CNS. Although one report, using a highly sensitive reverse transcription-PCR technique, showed the presence of GluR1 mRNA in the processes of cultured neurites (Miyashiro et al., 1994), most in situ hybridization studies of GluR1 mRNA have shown the transcript to be restricted to the cell body, making localized synthesis unlikely (Craig et al., 1993; Conti et al., 1994; Jakowec et al., 1995). Similarly, mRNA for $\mathrm{GABA}_{\mathrm{A}}$ receptor subunits has been shown to be confined to the cell body (Killisch et al., 1991), whereas a recent report has shown that the glycine receptor $\alpha$ subunit mRNA extends into the dendrite (Racca et al., 1997). At the protein level, the use of $\mathrm{C}$-terminal antibodies to study glutamate receptors has hindered the determination of whether surface or subsurface pools of receptors contribute to those at the synapse. Live cell staining with antibodies directed against extracellular epitopes of GluR1, 
now in progress, will help resolve this issue (also see Richmond et al., 1996).

\section{Heteromeric synaptic receptors}

In addition to GluR1, the AMPA receptor subunit GluR2/3 is present at the earliest sites of postsynaptic receptor clustering, likely as part of a heteromeric complex. GluR4 does not seem to be involved in early contacts, because it is expressed several days after the onset of synaptogenesis. By $11 \mathrm{~d}$ in vitro, all neurons that expressed GluR1 had multiple receptor clusters that also contained aggregated GluR2/3 and/or GluR4 at staining intensities that appeared similar from cluster to cluster within a given neuron. Because the multiple AMPA receptor clusters on any neuron reflect input from several different spinal neurons, their invariant subunit composition suggests that presynaptic terminals do not significantly influence the subunit expression pattern of postsynaptic receptor clusters. As mentioned previously, however, this concept requires further study.

Because the formation of receptor clusters appeared similar in all cultured spinal neurons despite differences in AMPA receptor subunit expression, it was natural to search for a subunit common to all heteromeric complexes that might serve as an anchor to postsynaptic cytoskeletal elements. By immunohistochemistry, GluR2 and/or GluR3 are present at nearly all receptor clusters in cultured spinal cord neurons. In addition, studies of AMPA receptor subunit expression in vivo have consistently shown that GluR2 and/or GluR3 are expressed in the vast majority of central neurons (Keinanen et al., 1990; Martin et al., 1993; Conti et al., 1994; Jakowec et al., 1995). Recent work in our laboratory (Dong et al., 1997) has shown that overexpression of the C-terminal tail of GluR2 and GluR3 but not GluR1 disrupts synaptic clustering in cultured spinal neurons, presumably through a dominantnegative process. The identification of molecules similar to the recently described GluR interacting protein GRIP (Dong et al., 1997), which bind to this highly conserved region, may shed considerable light on the mechanisms of postsynaptic receptor clustering.

\section{The NMDA receptor subunit NR1 is not clustered at excitatory synapses}

In cultured rat spinal neurons, the NMDA receptor subunit NR1 was not co-clustered with AMPA receptors at excitatory synapses. The antibodies used in our study span the entire length of NR1 and include both extracellular and intracellular pools. Because NR1 is a part of all NMDA receptor complexes (Nakanishi, 1992), these observations suggest that in our system, NMDA receptors remain diffusely distributed despite AMPA receptor aggregation. Data from our electrophysiological experiments are consistent with this observation, and imply, along with the $\mathrm{N}$-terminal staining in live neurons, that NMDA receptors are on the surface of these neurons. To date, the evidence that NMDA receptors are concentrated along with AMPA receptors at excitatory synapses is based on staining for NR1 and NR2B in spines of hippocampal and cortical neurons both in vivo and in vitro (Aoki et al., 1994; Huntley et al., 1994; Petralia et al., 1994; Lau and Huganir, 1995; Kharazia et al., 1996). The evidence that NMDA receptors are concentrated at excitatory synapses on dendritic shafts is more uncertain. The fact that NMDA and AMPA receptors are activated simultaneously at some dendritic shaft synapses in vitro (Bekkers and Stevens, 1989; Yu et al., 1997) is not evidence of co-clustering; a diff usely distributed but highly expressed population of NMDA receptors may also be activated by synaptic glutamate release, because of the higher affinity and larger conductance of NMDA receptors. In the only iontophoretic study that compared NMDA and AMPA receptor chemosensitivity in individual neurons, Jones and Baughman (1991) found, at most, a twofold variability in NMDA sensitivity in the face of large changes in AMPA receptor currents. Ultrastructural work in vivo has not consistently demonstrated NMDA receptor clusters on dendritic shafts, despite definite clusters on spines (Aoki et al., 1994; Huntley et al., 1994; Petralia et al., 1994). Inherent differences between spines and shafts or between the hippocampus and spinal cord, including the distribution of cytoskeletal binding proteins such as the PSD 95 family (Cho et al., 1992), or the expression of NR2 subunits (Kutsuwada et al., 1992; Tolle et al., 1993) may underlie the differences in receptor distribution. Although our observations imply that the clustering of AMPA receptors is independent of NMDA receptor aggregation in these cultures, they do not show that NMDA receptors are excluded from excitatory synapses. By examining mEPSCs, we are accentuating the disparities in distribution between NMDAand AMPA-type receptors attributable to the limited release of transmitter. In multivesicular-evoked release, however, there may be considerable spillover of transmitter into extrasynaptic sites (Kullmann et al., 1996), resulting in a major activation of NMDA receptors, given their higher glutamate affinity and larger conductances.

\section{Glutamate transporters are not clustered at excitatory synapses}

High-affinity transporters for glutamate have recently been cloned from both neurons and glia (Kanai and Hediger, 1992; Pines et al., 1992). We have found in cultures of rat spinal cord that $100 \%$ of the neurons express specific staining for EAAC1, which was diffusely distributed throughout cell bodies and dendrites. There was no evidence that the transporter was present in presynaptic terminals or concentrated at postsynaptic excitatory clusters. In vivo, Rothstein et al. (1994) found a somewhat punctate pattern of EAAC1 staining in neurons but did not attempt to correlate this with the presence or absence of excitatory synapses. They did note occasional evidence of concentrated staining in presynaptic elements, a pattern absent in our cultures. GLT1 was present in half the glial cells in our cultures, again without evidence of focal accumulations. This pattern is quite similar to that reported in vivo by Rothstein et al. (1994) and Danbolt et al. (1992). The distribution of both glutamate transporters was quite unlike that of a molecule involved in synaptic termination, such as acetylcholinesterase (Rubin et al., 1980), which is highly concentrated at the neuromuscular junction. Indeed the rate of decay of excitatory synaptic currents in our cultures was comparable to any found in vivo (Colquhoun et al., 1992; Livsey et al., 1993), making it unlikely that the lack of transporter accumulation detrimentally affected synaptic kinetics. The distribution of these transporters is more consistent with the regulation of global glutamate concentrations rather than the regulation of synaptic kinetics. In addition, the lack of transporter staining in presynaptic terminals makes it unlikely that these transporters are involved in presynaptic glutamate recycling. It is possible that other transporters, yet to be characterized, will play a role in excitatory synaptic transmission.

\section{REFERENCES}

Anderson MJ, Cohen MJ (1977) Nerve-induced spontaneous redistribution of acetylcholine receptors on cultured muscle cells. J Physiol (Lond) 268:757-773. 
Aoki C, Venkatesan C, Go CG, Mong JA, Dawson TM (1994) Cellular and subcellular distribution of NMDA-R1 subunit immunoreactivity in the visual cortex of the adult and neonatal rats. J Neurosci 14:5202-5222.

Aplin JD, Hughes RC (1981) protein-derivatized glass coverslips for the study of cell-to-substratum adhesion. Anal Biochem 113:144-148.

Baude A, Nusser Z, Molnar E, McIlhinney RA, Somogyi P (1995) High resolution immunogold localization of AMPA type receptor subunits at synaptic and non-synaptic sites in rat hippocampus. Neuroscience 69:1031-1055.

Bechade C, Colin I, Kirsch J, Betz H, Triller A (1996) Expression of glycine receptor subunits and gephyrin in cultured spinal neurons. Eur J Neurosci 8:429-435.

Bekkers JM, Stevens CF (1989) NMDA and non-NMDA receptors are co-localized at individual excitatory synapses in cultured rat hippocampus. Nature 341:230-232.

Blackstone CD, Moss SJ, Martin LJ, Levey AI, Price DL, Huganir RL (1992) Biochemical characterization of a non-NMDA receptor in rat brain. J Neurochem 58:1118-1126.

Bowe MA, Fallon JR (1995) The role of agrin in synapse formation. Annu Rev Neurosci 18:443-462.

Cho KO, Hunt CA, Kennedy MB (1992) The rat brain postsynaptic density fraction contains a homolog of the Drosophila discs-large tumor suppressor protein. Neuron 9:929-942.

Colquhoun D, Jonas P, Sakmann B (1992) Action of brief pulses of glutamate on AMPA receptors in patches from different neurons of rat hippocampal slices. J Physiol (Lond) 458:261-287.

Conti F, Minelli A, Brecha NC (1994) Cellular localization and laminar distribution of AMPA receptor subunit mRNAs and proteins in the rat cerebral cortex. J Comp Neurol 350:241-259.

Craig AM, Blackstone CD, Huganir RL, Banker G (1993) The distribution of glutamate receptors in cultured rat hippocampal neurons: postsynaptic clustering of AMPA specific subunits. Neuron 10:1055-1068.

Craig AM, Blackstone CD, Huganir RL, Banker G (1994) Selective clustering of glutamate and GABA receptors opposite terminals releasing the corresponding neurotransmitters. Proc Natl Acad Sci USA 91:12373-12377.

Danbolt NC, Storm-Mathisen J, Kanner BI (1992) An $\left[\mathrm{Na}^{+} / \mathrm{K}^{+}\right]$coupled L-glutamate transporter purified from rat brain is located in glial cell processes. Neuroscience 51:295-310.

Dong H, O'Brien RJ, Fung ET, Lanahan AA, Worley PF, Huganir RL (1997) Isolation of GRIP, a synaptic PDZ domain containing protein which interacts with AMPA receptors. Nature 386:279-284.

Falls DL, Rosen KM, Corfas G, Lane WS, Fischbach GD (1993) ARIA, a protein that stimulates acetylcholine receptor synthesis, is a member of the neu ligand family. Cell 72:801-815.

Frank E, Fischbach GD (1979) Early events in neuromuscular junction formation in vitro. Induction of acetylcholine receptors in the postsynaptic membrane and morphology of newly formed nerve-muscle synapses. J Cell Biol 83:143-158.

Goslin K, Banker G (1991) Rat hippocampal neurons in low-density culture. In: Culturing nerve cells (Banker G, Goslin K, eds), pp 251281. Cambridge, MA: MIT.

Hall ZW, Sanes JR (1993) Synaptic structure and function: the neuromuscular junction. Neuron 10:99-121.

Henderson CE, Camu W, Mettling C, Gouin A, Poulsen K, Karihaloo M, Rullamas J, Evans T, McMahon SB, Armanini MP, Berkemeier L, Phillips HS, Rosenthal A (1993) Neurotrophins promote motor neuron survival and are present in embryonic limb bud. Nature 363:266-269.

Hollmann M, Heinemann S (1994) Cloned glutamate receptors. Annu Rev Neurosci 17:31-108.

Holmes WR (1995) Modeling the effect of glutamate diffusion and uptake on NMDA and non-NMDA receptor saturation. Biophys $\mathrm{J}$ 69:1734-1747.

Huettner JE, Baughman R (1986) Primary cultures of identified neurons from the visual cortex of postnatal rats. J Neurosci 6:3044-3060.

Huntley GW, Vicker JC, Janssen W, Brose N, Heinemann SF, Morrison JH (1994) Distribution and synaptic localization of immunocytochemically identified NMDA receptor subunit proteins in sensorymotor and visual cortices of monkey and human. J Neurosci 14:3603-3619.

Isaac JR, Nicoll RA, Malenka RC (1995) Evidence for silent synapses: implications for the expression of LTP. Neuron 15:427-434.
Jakowec MW, Yen L, Kalb RG (1995) In situ hybridization analysis of AMPA receptor subunit gene expression in the developing rat spinal cord. Neuroscience 67:909-920.

Jones KA, Baughman RW (1991) Both NMDA and non-NMDA subtypes of glutamate receptors are concentrated at synapses on cerebral cortical neurons in culture. Neuron 7:593-603.

Kanai Y, Hediger MA (1992) Primary structure and functional characterization of a high affinity glutamate transporter. Nature 360:467-471.

Keinanen K, Wisden W, Sommer B, Werner P, Herb A, Verdoorn TA, Sakmann B, Seeburg PH (1990) A family of NMDA selective glutamate receptors. Science 249:556-560.

Kharazia VN, Phend KD, Rustioni A, Weinberg RJ (1996) EM colocalization of AMPA and NMDA receptor subunits at synapses in rat cerebral cortex. Neurosci Lett 210:37-40.

Kharazia VN, Wenthold RJ, Weinberg RJ (1996) GluR1-immunopositive interneurons in rat neocortex. J Comp Neurol 368:399-412.

Killisch I, Dotti CG, Laurie DJ, Luddens H, Seeburg PH (1991) Expression patterns of GABAA receptor subtypes in developing hippocampal neurons. Neuron 7:927-936.

Kirsch J, Wolters I, Triller A, Betz H (1993) Gephyrin antisense oligonucleotides prevent glycine receptor clustering in spinal neurons. Nature 366:745-748.

Kullmann DM, Erdemli G, Asztely F (1996) LTP of AMPA and NMDA receptor mediated signals: evidence presynaptic expression and extrasynaptic glutamate spill-over. Neuron 17:461-474.

Kutsuwada T, Kashiwabuchi N, Mori H, Sakimura K, Kushiya E, Araki K, Meguro H, Masaki H, Kumanishi T, Arakawa M, Mishina M (1992) Molecular diversity of the NMDA receptor channel. Nature 358:36-41.

Lau LF, Huganir RL (1995) Differential tyrosine phosphorylation of NMDA receptor subunits. J Biol Chem 270:20036-20041.

Livsey CT, Costa E, Vicini S (1993) Glutamate activated currents in outside-out patches from spiny versus aspiny hilar neurons of rat hippocampal slices. J Neurosci 13:5324-5333.

Martin LJ, Blackstone CD, Levey AI, Huganir RL, Price DL (1993) AMPA receptor subunits are differentially distributed in rat brain. Neuroscience 53:327-358.

Miyashiro K, Dichter M, Eberwine J (1994) On the nature and differential distribution of mRNAs in hippocampal neurites. Proc Natl Acad Sci USA 91:10800-10804.

Nakanishi S (1992) Molecular diversity of glutamate receptors and implications for brain function. Science 258:597-603.

Oertel WH, Schmechel DE, Mugnaini E (1984) Glutamate decarboxylase (GAD). In: Current methods in cellular neurobiology (Barker JL, Mckelvey JF, eds), pp 63-109. New York: Wiley.

O'Brien RJ, Fischbach GD (1986a) Isolation of embryonic chick motoneurons and their survival in vitro. J Neurosci 6:3265-3274.

O'Brien RJ, Fischbach GD (1986b) Modulation of embryonic chick motoneuron glutamate sensitivity by interneurons and agonists. J Neurosci 6:3290-3296.

Petralia RS, Wenthold RJ (1992) Light and electron immunocytochemical localization of AMPA-selective glutamate receptors in rat brain. J Comp Neurol 318:329-354.

Petralia RS, Yokotani N, Wenthold RJ (1994) Light and electron microscope distribution of the NMDA receptor subunit NMDAR1in the rat nervous system using a selective anti-peptide antibody. J Neurosci 14:667-696.

Pines G, Danbolt NC, Bjoras M, Zhang Y, Bendahan A, Eide L, Koepsell H, Storm-Mathisen J, Seeberg E, Kanner BI (1992) Cloning and expression of a rat brain L-glutamate transporter. Nature 360:464-467.

Racca C, Gardiol A, Triller A (1997) Dendritic and postsynaptic localization of glycine receptor a subunit mRNAs. J Neurosci 17:1691-1700.

Raymond LA, Blackstone CD, Huganir RL (1993) Phosphorylation and modulation of recombinant GluR6 glutamate receptor by cAMP dependent protein kinase. Nature 361:637-641.

Richmond SA, Irving AJ, Molnar E, McIlhinney RAJ, Michelangeli F, Henley JM, Collingridge GL (1996) Localization of the glutamate receptor subunit GluR1 on the surface of living cultured hippocampal neurons. Neuroscience 75:69-82.

Rothstein JD, Martin L, Levey AI, Dykes-Hoberg M, Jin L, Wu D, Nash N, Kuncl RW (1994) Localization of neuronal and glial glutamate transporters. Neuron 13:713-725. 
Rubin LL, Schuetze SM, Weill CL, Fischbach GD (1980) Regulation of acetylcholinesterase appearance at neuromuscular junctions in vitro. Nature 283:264-267.

Segal MM, Furshpan EJ (1990) Epileptiform activity in microcultures containing small numbers of hippocampal neurons. J Neurophysiol 64:1390-1399.

Sheng M, Cummings J, Roldan LA, Jan YN, Jan LY (1994) Changing subunit composition of heteromeric NMDA receptors during development of the rat cortex. Nature 368:144-147.

Tingley WG, Roche KW, Thompson AK, Huganir RL (1993) Regulation of NMDA receptor phosphorylation by alternative splicing of the C-terminal domain. Nature 364:70-73.

Todd AJ, Spike RC, Chong D, Neilson M (1995) The relationship between glycine and gephyrin in synapses of the rat spinal cord. Eur J Neurosci 7:1-11.

Tolle TR, Berthele A, Zieglgansberger W, Seeburg PH, Wisden W
(1993) The differential expression of 16 NMDA and non-NMDA receptor subunits in the rat spinal cord and periaqueductal gray. J Neurosci 13:5009-5028.

Triller A, Cluzeaud F, Korn H (1987) Gamma-aminobutyric acidcontaining terminals can be apposed to glycine receptors at central synapses. J Cell Biol 104:947-956.

Trussell LO, Fischbach GD (1989) Glutamate receptor desensitization and its role in synaptic transmission. Neuron 3:209-218.

Trussell LO, Thio LL, Zorumski CF, Fischbach GD (1988) Rapid desensitization of glutamate receptors in vertebrate central neurons. Proc Natl Acad Sci USA 85:4562-4566.

Vaughn JE (1989) Fine structure of synaptogenesis in the vertebrate central nervous system. Synapse 3:255-285.

Yu XM, Askalan R, Keil GJ, Salter MW (1997) NMDA channel regulation by channel associated protein tyrosine kinase Src. Science 275: 674-678. 